\title{
Efektivitas Pembelajaran Matematika melalui Penerapan Metode Field Trip pada Kelas VII
}

\author{
Hamzah Upu ${ }^{1, a)}$, Darwis ${ }^{1, b)}$, dan Athira ${ }^{1, c)}$ \\ ${ }^{1}$ Jurusan Matematika, Fakultas MIPA, Universitas Negeri Makassar

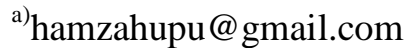 \\ b)muhammaddarwis@gmail.com \\ ${ }^{c)}$ nathira79@gmail.com
}

\begin{abstract}
Abstrak. Penelitian ini bertujuan untuk mengetahui efektivitas pembelajaran matematika melalui penerapan metode Field Trip pada kelas VII ditinjau dari hasil belajar, aktivitas, dan respon siswa. Penelitian ini adalah penelitian kuantitatif dengan pendekatan pra-eksperimen dengan teknik pengambilan sampel yaitu cluster random sampling. Pengambilan data dilakukan dengan menggunakan lembar observasi keterlaksanaan pembelajaran, tes hasil belajar (pretest dan posttest), lembar observasi aktivitas siswa, dan angket respons siswa. Teknik analisis data yang digunakan adalah teknik analisis deskriptif dan inferensial. Hasil analisis deskriptif menunjukkan: (1) rata-rata hasil pretest siswa yaitu 20,5(kategori sangat rendah), rata-rata hasil posttest siswa yaitu 77,7(kategori tinggi) (2) rata-rata hasil posttest menunjukkan ketuntasan klasikal tercapai yakni sebesar 90\% (18 siswa), (3) rata-rata gain ternormalisasi sebesar 0,7(kategori tinggi), (4) rata-rata aktivitas siswa sebesar 92\% (kategori sangat aktif), (5) rata-rata presentase siswa yang memberi respon positif sebanyak 94\%. Hasil analisis inferensial menunjukkan: (1) nilai rata-rata hasil belajar siswa yang diajar dengan metode Field Trip lebih besar dari 70 (KKM), (2) nilai rata-rata gain ternormalisasi lebih besar dari 0,3, (3) persentase respon siswa lebih besar dari 70\%. Dari hasil penelitian ini dapat disimpulkan bahwa pembelajaran dengan penerapan metode Field Trip efektif diterapkan pada siswa kelas VII SMP.
\end{abstract}

Kata Kunci: Efektivitas, Hasil Belajar, Aktivitas, Respons, Metode Field Trip.

\begin{abstract}
This research aims to determine the effectiveness of learning mathematics through the application of the Field Trip method in class VII based on student learning outcomes, activity, and student responses. This research is quantitative approachwithpre-experimental study and sampling technique used is cluster random sampling. Data analysis technique used is descriptive and inferential analysis techniques. The results of descriptive analysis showed: (1) average results of students' pretest was 20,5(very lo category), average student posttest result was 77,7(high category) (2) the posttest results showed that classical completeness was reached student activity at 90\% (18 students), (3) average normalized gain was 0.7(high category), (4) average student activity was $92 \%$ (very good category), (5) average percentage of students who gave positive response of 94\%. Inferential analysis results show: (1) the average value of students after being taught with the fieldtrip learning method is greater than 70, (2) the normalized average gain value is greater than 0.3 (medium category), (3) the percentage of positive student responses greater than $70 \%$. From the results of this study it can be concluded that learning by applying the Field Trip methods is effectively applied to students of grade VII.
\end{abstract}

Keywords: Effectiveness, Learning Achievement, Student Activity, Field Trip Methods, Mathematics Learning 


\section{PENDAHULUAN}

Hasil belajar merupakan salah satu tujuan yang hendak dicapai pada proses pembelajaran di sekolah. Peningkatan hasil belajar pada dasarnya berkorelasi positif dengan keberhasilan pembelajaran (Hamzah, 2014). Penilaian hasil belajar menyangkut aspek kognitif, afektif, dan psikomotorik sebagai hasil perubahan tingkah laku dari kegiatan belajar (Haling, 2007). Namun pada kenyataannya dapat dilihat bahwa hasil belajar matematika yang dicapai siswa masih perlu ditingkatkan (Prasetyo, 2015).

Hasil belajar siswa pada umumnya dipengaruhi oleh dua faktor yang saling berhubungan, yakni internal dan ekternal (Slameto, 2010). Faktor internal yang dimaksud salah satunya adalah minat dan motivasi belajar siswa. Sedangkan faktor eksternal adalah cara guru dalam menerapkan metode pembelajaran. Penerapan metode pembelajaran yang tepat dapat mempengaruhi minat dan semangat siswa sebagai upaya dalam meningkatkan hasil belajar.

Metode pembelajaran adalah cara menyajikan materi pelajaran yang dilakukan oleh pendidik agar terjadi proses pembelajaran pada diri siswa dalam upaya untuk mencapai tujuan (Sutikno, 2009). Metode pembelajaran tersebut dimaksudkan sebagai upaya menciptakan lingkungan belajar yang kondusif. Semakin tepat metode yang digunakan oleh guru dalam mengajar, maka semakin efektif pula pencapaian tujuan pembelajaran (Fathurrohman \& Sutikno, 2015).

Kedudukan metode pembelajaran adalah sebagai alat motivasi ekstrinsik, strategi pengajaran, serta alat untuk mencapai tujuan pendidikan (Djamarah, Bahri, \& Zain, 2010). Guru sebagai pendidik diharapkan memiliki strategi yang mampu meningkatkan efektivitas dan efisiensi belajar siswa. Strategi pembelajaran tersebut dimaksudkan agar tercipta proses belajar yang lebih mandiri, kreatif, dan aktif pada siswa. Salah satu strategi atau alternatif yang dapat meningkatkan aktivitas siswa dalam proses pembelajaran adalah metode pembelajaran Field Trip.

Metode Field Trip merupakan metode pembelajaran yang dilaksanakan di luar kelas. Kegiatan yang dilakukan adalah mengajak siswa memecahkan masalah langsung objek yang dipelajari. Pembelajaran di luar kelas memiliki dampak pada peningkatan aspek-aspek psikologis siswa, seperti rasa senang, rasa kebersamaan, dan motivasi belajar siswa (Anitah, 2009). Metode ini membuat siswa dapat berperan aktif dalam proses pembelajaran akibatnya pembelajaran lebih beramakna.

Beberapa penelitian telah menggunakan metode pembelajaran Field Trip, akan tetapi bukan pada bidang matematika.; Yuliati \& Martuti (2014) dalam bidang IPA; Fadillah (2016) dalam bidang Bahasa Indonesia; dan Ubaidillah (2018) dalam bilang Fisika.

Pada penelitian ini akan mengkaji tentang pembelajaran matematika dengan menerapkan metode Field Trip. Penelitian ini berfokus pada hasil belajar, aktivitas, dan respons siswa. Soal matematika yang diberikan mengenai materi tentang penyajian data.

\section{KAJIAN PUSTAKA}

Metode Field Trip adalah salah satu metode pembelajaran yang dilaksanakan dengan cara mengajak peserta didik berkunjung ke suatu tempat di luar lingkungan sekolah (Ruhimat, 2017). Metode Field Trip digunakan oleh pendidik untuk membawa pengalaman belajar yang ada di luar sekolah ke dalam sekolah (Wang \& Carlson, 2011).

Pelaksanaan field trip memberikan pengalaman unik pada siswa dengan menampilkan meteri pelajaran secara nyata. Adanya metode pembelajaran Field Trip mengajak siswa untuk memecahkan masalah langsung yang sesuai dengan materi pembelajaran yang sedang dipelajari. Hal ini berdampak terciptanya suasana kelas yang mandiri, kreatif, dan lebih aktif. 
Metode pembelajaran field trip memiliki beberapa keunggulan (Abimanyu, 2008), yaitu:

1. Siswa dapat belajar langsung di lapangan, pengetahuan yang diperoleh nyata, hidup, bermakna dan komprehensif;

2. Siswa dapat menemukan sendiri jawaban dari masalah atau pertanyaan tentang materi yang dipelajari;

3. Motivasi dan minat belajar siswa tinggi; siswa aktif belajar melalui observasi, wawancara, percobaan, menggolong- golongkan dan sebagainya.

Selain itu, ada beberapa kelemahan dari metode field trip (Asmani, 2010), yaitu:

1. Memerlukan persiapan yang melibatkan banyak pihak;

2. Memerlukan waktu yang cukup lama;

3. Memerlukan pengawasan yang ketat agar siswa fokus terhadap tugasnya; serta

4. Laporan hasil biasanya diserahkan tidak tepat waktu.

Beberapa penelitian telah mengkaji terkait metode pembelajaran field trip. Fadillah (2016) meneliti dalam bidang Bahasa Indonesia. Penelitian ini mengkaji tentang penerapan metode field trip untuk meningkatkan kemampuan menulis deskripsi. Hasil penelitian ini menunjukkan bahwa penerapan metode field trip untuk meningkatkan kemampuan menulis deskripsi.

Penelitian terkait juga dilakukan oleh Yuliati \& Martuti (2014) dalam bidang IPA. Penelitian ini mengkaji tentang efektivitas penerapan metode Field Trip dalam meningkatkan hasil belajar dan kepedulian siswa terhadap lingkungan. Hasil penilitian menunjukkan bahwa penerapan metode Field Trip efektif dalam meningkatkan hasil belajar dan kepedulian siswa terhadap lingkungan.

\section{METODE PENELITIAN}

Jenis penelitian yang digunakan adalah jenis penelitian kuantitatif dengan pendekatan praeksperimen. Desain penelitian dalam penelitian ini ditunjukkan pada Tabel 1.

TABEL 1. Desain Penelitian One Group - Pretest Posttest Design

\begin{tabular}{ccc} 
Pretest & Variabel Terikat & Posttest \\
\hline $\mathrm{O}_{1}$ & $\mathrm{X}$ & $\mathrm{O}_{2}$ \\
\hline
\end{tabular}

Keterangan :

$\mathrm{O}_{1} \quad$ : tes awal (pretest) sebelum perlakuan diberikan

$\mathrm{O}_{2} \quad$ : tes akhir (posttest) setelah perlakuan diberikan

$\mathrm{X}$ : perlakuan terhadap kelompok eksperimen yaitu dengan menerapkan metode pembelajaran Field Trip

Penelitian ini dilaksanakan di kelas VII pada tingkat MTs. Sampel dalam penelitian ini terdiri dari 20 siswa. Ada dua jenis variabel dalam penelitian ini yaitu variabel bebas dan variabel terikat. Variabel bebas dalam penelitian ini adalah pembelajaran dengan menggunakan metode pembelajaran Field Trip. Sedangkan variabel terikatnya adalah hasil belajar, aktivitas siswa, dan respons siswa.

Teknik pengumpulan data dilakukan dengan tes, angket, dan observasi. Instrumen yang digunakan yaitu lembar observasi keterlaksanaan pembelajaran, tes hasil belajar, lembar observasi aktivitas siswa, dan angket respon siswa. Instrumen telah divalidasi oleh dua ahli.

Analisis data yang digunakan pada penelitian ini yaitu analisis statistik deskriptif dan analisis statistik inferensial. Analisis statistik deskriptif digunakan untuk mendeskripsikan setiap variabel penelitian. Analisis statistik inferensial digunakan untuk menguji hipotesis penelitian Namun, sebelumnya dilakukan uji prasyarat yaitu uji normalitas.

Kriteria efektivitas dalam penelitian ini adalah skor rata-rata posttest siswa setelah diajar dengan menggunakan metode pembelajaran Field Trip minimal memenuhi KKM, peningkatan hasil belajar siswa minimal berada pada kategori "sedang", proporsi ketuntasan belajar siswa secara 
klasikal setelah diterapkan metode pembelajaran Field Trip minimal 70\%, aktivitas siswa selama proses pembelajaran berlangsung lebih besar $70 \%$, presentase siswa yang merespons positif penerapan metode pembelajaran Field Trip minimal $70 \%$.

\section{HASIL DAN PEMBAHASAN}

Penelitian dilaksanakan dengan 1 pertemuan, 1 pertemuan pemberian pretest, 1 pertemuan pemberian posttest, dan 3 pertemuan pemberian pembelajaran dengan menggunakan metode pembelajaran Field Trip. Pretest merupakan tes awal yang diberikan sebelum pembelajaran dilaksanakan. Sedangkan, posttest merupakan tes akhir setelah pembelajaran dilaksanakan. Selain itu, selama proses pembelajaran berlangsung, dilakukan pengisian lembar observasi keterlaksanaan pembelajaran dan lembar observasi aktivitas siswa. Angket respon siswa diisi oleh siswa setelah pembelajaran dilaksanakan.

\section{Keterlaksanaan Metode Pembelajaran Field Trip}

Di awal pembelajaran, guru mengarahkan siswa, membagi kelompok dan ikut serta mengatur siswa kemudian memberi penjelasan kepada siswa cara bekerja dalam kelompok. Selanjutnya guru menyampaikan garis-garis besar proses pembelajaran dan kemudian membagikan LKS. Setelah LKS dibagikan kepada siswa, siswa kemudian harus mengerjakan LKS tersebut dengan melakukan observasi dan wawancara di luar kelas.

Pada saat proses pembelajaran, guru mengawasi siswa serta melakukan evaluasi terhadap sikap siswa dalam pengerjaan LKS. Setelah siswa melakukan kegiatan di luar kelas, siswa diminta untuk menulis laporan hasil kelompoknya dan diminta untuk mempresentasikan di depan kelas.

Berikut disajikan pula hasil rekapitulasi persentase aktivitas guru pada setiap pertemuan.

TABEL 2. Rekapitulasi Hasil Observasi Keterlaksanaan Pembelajaran

\begin{tabular}{ccc} 
Pertemuan & Rata-rata & Kategori \\
\hline 1 & 3,7 & Terlaksana dengan baik \\
2 & 3,7 & Terlaksana dengan baik \\
3 & 3,7 & Terlaksana dengan baik \\
\hline Rata-rata & 3,7 & Terlaksana dengan baik \\
\hline
\end{tabular}

Pada Tabel 2, secara kuantitatif menunjukkan bahwa untuk skor rata-rata semua pertemuan yaitu 3,7 dan berada pada interval $(3,5-4,0)$. Maka dapat disimpulkan secara keseluruhan observasi terhadap keterlaksanaan metode pembelajaran Field Trip dikatakan "terlaksana dengan baik". Secara kualitatif, guru melaksanakan semua aspek dalam kegiatan pembelajaran. Selain itu, guru memperhatikan kesediaan siswa dalam melaksanakan perintah atau arahan dari guru dan siswa memberikan respon terhadap arahan tersebut. Akan tetapi, terkadang guru tidak memperhatikan dan tidak memberikan respon balik terhadap respon yang diberikan siswa.

\section{Hasil Belajar Siswa}

\section{Analisis Deskriptif}

Data yang diperoleh dalam penelitian adalah data tentang hasil tes belajar matematika siswa. Data dideskripsikan berdasarkan analisis data tes awal (pretest) dan tes akhir (posttest).

Tabel 3 menunjukkan bahwa rata-rata pretest siswa adalah 20,5 dari skor ideal 100 yang mungkin dicapai siswa. Skor rata-rata tersebut menunjukkan bahwa hasil belajar yang dimiliki siswa masih rendah. Skor Nilai median pretest sebesar 18,5 menunjukkan bahwa sekitar 50\% siswa memperoleh nilai paling tinggi 18,5 atau paling rendah 18,5 . Skor yang dicapai siswa tersebar dari skor 9 sampai dengan 37 dengan rentang 28 . 
TABEL 3.Rekapitulasi Hasil Tes Belajar Siswa

\begin{tabular}{ccc}
\hline Statustik & Pretest & Posttest \\
\hline Ukuran Sampel & 20 & 20 \\
Mean & 20,5 & 77,7 \\
Median & 18,5 & 77 \\
Standar deviasi & 8,9 & 9,4 \\
Nilai tertinggi & 37 & 91 \\
Nilai terendah & 9 & 54 \\
Range & 28 & 37 \\
\hline
\end{tabular}

Rata-rata posttest siswa adalah 77,7 dari skor ideal 100 yang mungkin dicapai siswa. Skor ratarata tersebut menunjukkan bahwa hasil belajar yang dimiliki siswa telah meningkat. Nilai median posttest sebesar 77 menunjukkan bahwa sekitar 50\% siswa memperoleh nilai paling tinggi 77 atau paling rendah 77. Skor yang dicapai siswa tersebar dari skor 54 sampai dengan 91 dengan rentang 37 . Selanjutnya kategori kemampuan pretest dan posttest pada kelas eksperimen disajikan pada Tabel 4.

TABEL 4. Distribusi Frekuensi Tingkat Kemampuan Siswa

\begin{tabular}{cccccc}
\hline \multirow{2}{*}{ Interval } & $\begin{array}{c}\text { Kategori } \\
\text { penguasaan }\end{array}$ & \multicolumn{2}{c}{ Pretest } & \multicolumn{2}{c}{ Posttest } \\
\cline { 3 - 6 } & Siswa & Frekuensi & $\begin{array}{c}\text { Persentase } \\
(\%)\end{array}$ & Frekuensi & Persentase \\
& & & 100 & 0 & $(\%)$ \\
\hline $0 \leq x<40$ & Sangat rendah & 20 & 0 & 1 & 0 \\
$40 \leq x<60$ & Rendah & 0 & 0 & 3 & 5 \\
$60 \leq x<75$ & Sedang & 0 & 0 & 14 & 15 \\
$75 \leq x<90$ & Tinggi & 0 & 0 & 2 & 70 \\
$90 \leq x \leq 100$ & Sangat tinggi & 0 & 100 & 20 & 10 \\
\hline \multicolumn{2}{c}{ Jumlah } & 20 & &
\end{tabular}

Tabel 4 menunjukkan bahwa semua nilai pretest siswa hanya berada dalam 1 kategori saja, yaitu kategori sangat rendah. Tidak satupun siswa yang memperoleh nilai dalam kategori rendah, sedang, tinggi, dan sangat tinggi. Sebaliknya untuk nilai posttest juga berada dalam 4 kategori saja, yaitu rendah, sedang, tinggi dan sangat tinggi. Sehingga dapat disimpulkan bahwa secara deskriptif terjadi peningkatan hasil belajar siswa setelah diterapkan metode pembelajaran Field Trip dalam mata pelajaran matematika untuk materi penyajian data.

Dari Tabel 5, terlihat bahwa mean peningkatan nilai siswa untuk metode pembelajaran Field Trip adalah 0,7 . Hal ini menunjukkan bahwa secara umum peningkatan nilai siswa dari pretest ke posttest berada pada kategori tinggi. Nilai median sebesar peningkatan nilai siswa sebesar 0,7 menunjukkan bahwa ada sekitar 50\% siswa yang peningkatan nilainya paling tinggi 0,7 atau paling rendah 0,7 . Jika peningkatan hasil belajar matematika siswa dikelompokkan ke dalam 5 kategori maka diperoleh distribusi frekuensi dan persentase Tabel 6. 
IMED 5(1) 2021, hal. $82-90$

TABEL 5.Rekapitulasi Peningkatan Nilai Siswa

\begin{tabular}{cc} 
Statistik & Gain \\
\hline Mean & 0,7 \\
Median & 0,7 \\
Standar deviasi & 0,13 \\
Koefisien varians & $19 \%$ \\
Nilai tertinggi & 0,9 \\
Nilai terendah & 0,4 \\
Range & 0,5 \\
Skewness & $-1,112$ \\
\hline
\end{tabular}

TABEL 6. Klasifikasi gain ternormalisasi Nilai Siswa

\begin{tabular}{|c|c|c|c|}
\hline $\begin{array}{c}\text { Koefisien } \\
\text { normalisasi gain } \\
\end{array}$ & Jumlah siswa & $\begin{array}{c}\text { Persentase } \\
(\%)\end{array}$ & Klasifikasi \\
\hline $\mathrm{g}<0,3$ & 0 & 0 & Rendah \\
\hline $0,3 \leq \mathrm{g}<0,7$ & 8 & 40 & Sedang \\
\hline $\mathrm{g} \geq 0,7$ & 12 & 60 & Tinggi \\
\hline Rata-rata & \multicolumn{2}{|c|}{0,71} & Tinggi \\
\hline
\end{tabular}

Pada Tabel 6, dapat dilihat bahwa peningkatan hasil belajar siswa yang diajar menggunakan metode pembelajaran Field Trip sebagian besar berada pada kategori sedang yaitu sebanyak $60 \%$ siswa. Hal ini menunjukkan siswa mengalami peningkatan hasil belajar siswa berkembang. Sedangkan, 20\% siswa berada dalam kategori rendah. Hal ini terjadi karena peningkatan hasil belajar siswa dari skor pretest dan posttest rendah sehingga hasil belajar siswa kurang berkembang.

TABEL 7. Pencapaian Kriteria (KKM) Nilai Posttest Siswa

\begin{tabular}{|c|c|c|c|c|}
\hline No. & Skor & Kategori & Frekuensi & Persentase \\
\hline 1 & $<70$ & Tidak Tuntas & 2 & $10 \%$ \\
\hline \multirow[t]{2}{*}{2} & \multirow[t]{2}{*}{$\geq 70$} & Tuntas & 18 & $90 \%$ \\
\hline & & & 20 & $100 \%$ \\
\hline
\end{tabular}

Tabel 7 menunjukkan bahwa hasil posttest, siswa yang memenuhi kriteria ketuntasan individu sebanyak 18 siswa atau $90 \%$. Jika dikaitkan dengan indikator ketuntasan hasil belajar maka dapat disimpulkan bahwa posttest hasil belajar memenuhi indikator ketuntasan hasil belajar siswa secara klasikal. Dengan demikian dapat disimpulkan bahwa secara deskriptif hasil belajar siswa setelah diterapkan metode pembelajaran Field Trip dalam mata pelajaran matematika untuk materi penyajian data efektif.

\section{Analisis Inferensial}

Pada analisis inferensial, dilakukan uji normalitas untuk hasil posttest belajar siswa yang diperoleh $p$-value $>\alpha$ yaitu 0,066>0,05. Peningkatan (nilai gain ternormalisasi) hasil belajar siswa diperoleh $p$-value $>\alpha$ yaitu $0,200>0,05$. Hal ini menunjukkan bahwa data hasil posttest belajar siswa dan data peningkatan (nilai gain ternormalisasi) belajar siswa berasal dari populasi yang berdistribusi normal.

Selanjutnya pengujian hipotesis untuk nilai posttest menunjukkan bahwa $t=3,667$ dengan derajat kebebasan $=19$ dan $p$-value $=0,002$. Karena $p<\alpha$ maka $\mathrm{H}_{\mathrm{o}}$ ditolak dengan kata lain $\mathrm{H}_{1}$ diterima. Ini berarti bahwa untuk nilai posttest belajar siswa menunjukkan bahwa nilai rata- 
rata posttest lebih dari 70. Proporsi siswa mencapai kriteria pencapaian KKM lebih dari 69\% (minimal 70\%). Serta peningkatan hasil belajar siswa menunjukkan nilai rata-rata gain ternormalisasi lebih dari 0,3 (kategori sedang).

\section{Aktivitas Siswa}

Hasil observasi tentang aktivitas siswa ditunjukkan oleh Tabel 8 . Tabel 8 menunjukkan bahwa aspek yang diamati pada observasi aktivitas siswa memenuhi kriteria efektif dimana skor ratarata untuk semua pertemuan yaitu 3,77 atau $92 \%$. Dengan skor berada pada interval $(3,5-4,0)$ pada kategori "sangat aktif". Hal ini menunjukkan bahwa kriteria keefektifan pembelajaran untuk aktivitas siswa terpenuhi.

TABEL 8. Rekapitulasi Hasil Observasi Aktivitas Siswa

\begin{tabular}{|c|c|c|c|c|c|}
\hline \multirow[t]{2}{*}{$\begin{array}{l}\text { Aspek yang } \\
\text { diobservasi }\end{array}$} & \multicolumn{3}{|c|}{$\begin{array}{l}\text { Skor rata-rata aktivitas } \\
\text { siswa setiap pertemuan }\end{array}$} & \multirow[t]{2}{*}{$\begin{array}{l}\text { Rata- } \\
\text { rata }\end{array}$} & \multirow[t]{2}{*}{ Kategori } \\
\hline & I & II & III & & \\
\hline 1 & 4 & 4 & 4 & 4 & Sangat Aktif \\
\hline 2 & 4 & 4 & 4 & 4 & Sangat Aktif \\
\hline 3 & 4 & 3 & 3 & 3,3 & Aktif \\
\hline 4 & 2 & 4 & 4 & 3,3 & Aktif \\
\hline 5 & 3 & 4 & 4 & 3,7 & Sangat Aktif \\
\hline 6 & 4 & 3 & 4 & 3,7 & Sangat Aktif \\
\hline 7 & 4 & 4 & 4 & 4,0 & Sangat Aktif \\
\hline 8 & 3 & 4 & 4 & 3,7 & Sangat Aktif \\
\hline 9 & 3 & 4 & 4 & 3,7 & Sangat Aktif \\
\hline 10 & 4 & 4 & 4 & 4 & Sangat Aktif \\
\hline 11 & 2 & 3 & 4 & 3 & Aktif \\
\hline 12 & 3 & 3 & 3 & 4 & Sangat Aktif \\
\hline 13 & 4 & 3 & 4 & 3,7 & Sangat Aktif \\
\hline 14 & 4 & 4 & 4 & 4 & Sangat Aktif \\
\hline 15 & 4 & 4 & 4 & 4 & Sangat Aktif \\
\hline Rata-rata & 3,5 & 3,7 & 3,9 & 3,7 & Sangat Aktif \\
\hline Persentase (\%) & 87 & 92 & 98 & 92 & \\
\hline
\end{tabular}

\section{Respon Siswa}

\section{Analisis Deskriptif}

TABEL 9. Data Angket Respon Siswa

\begin{tabular}{cccc}
\hline \multirow{2}{*}{$\begin{array}{c}\text { Aspek yang } \\
\text { direspon }\end{array}$} & \multicolumn{2}{c}{ Respon Siswa } & Persentase (\%) \\
\cline { 2 - 4 } & Ya & Tidak & Ya \\
\hline 1 & 17 & 3 & $85 \%$ \\
2 & 20 & 0 & $100 \%$ \\
3 & 19 & 1 & $95 \%$ \\
4 & 18 & 2 & $90 \%$ \\
5 & 20 & 0 & $100 \%$ \\
6 & 18 & 2 & $90 \%$ \\
7 & 19 & 1 & $95 \%$ \\
8 & 19 & 1 & $85 \%$ \\
9 & 20 & 0 & $100 \%$ \\
10 & 17 & 3 & $85 \%$ \\
\hline \multicolumn{5}{c}{ Rata-rata } \\
\hline
\end{tabular}


Tabel 9 menujukkan persentase rata-rata siswa yang memberi respon positif terhadap penerapan metode pembelajaran Field Trip sebesar 92\%. Dalam kriteria keefektifan, bahwa respons mahasiswa dikatakan efektif apabila lebih dari $70 \%$ siswa. Hal ini menunjukkan kriteria efektifitas pembelajaran untuk respon siswa terpenuhi.

\section{Analisis Inferensial}

Pengujian hipotesis untuk respons siswa yang ditanyakan $Z_{\text {hitung }}=2,41$ lebih besar dari $Z$ tabel yaitu 1,96 dengan $\alpha=0,05$. Sehingga disimpulkan bahwa karena Zhitung $>Z$ tabel, maka dapat dikatakan bahwa $H 0$ ditolak yang berarti persentase respons siswa lebih besar dari $70 \%$ setelah diajar dengan menggunakan metode Field Trip.

\section{KESIMPULAN}

Kesimpulan yang diperoleh dari penelitian ini yaitu metode pembelajaran Field Trip efektif diterapkan ditinjau dari aspek hasil belajar, aktivitas, respons, dan motivasi belajar siswa. Deskriptif efektivitas pembelajaran metode pembelajaran Field Trip sebagai berikut:

1. Pada aspek hasil belajar menunjukkan bahwa rata-rata hasil belajar yang dicapai pada pretest dan posttest sebesar 20,5 dan 77,7 dari skor minimal 70 . Dengan rata-rata peningkatan hasil belajar yaitu 0,71 . Sebanyak $90 \%$ pada posttest mencapai ketuntasan individu, berarti ketuntasan hasil belajar secara klasikal tercapai.

2. Pada aspek aktivitas mahasiswa dengan kriteria efektivitas minimal $70 \%$. Hasil menunjukkan bahwa rata-rata aktivitas siswa sebesar 92\% atau berada pada kategori sangat aktif.

3. Pada aspek respons mahasiswa dengan kriteria efektivitas minimal dari $70 \%$. Hasil menunjukkan bahwa penerapan metode pembelajaran Field Trip mendapat respons dengan kategori baik sekali sebesar $92 \%$ pada angket respons siswa terhadap pelaksanaan pembelajaran matematika.

Penelitian lanjutan dapat dikembangkan karena masih ada beberapa hal menarik yang dapat diteliti. Penerapan metode pembelajaran Field Trip dapat diterapkan sebagai metode pembelajaran untuk mengukur variabel lain selain hasil belajar, aktivitas, serta respons siswa. Selain itu, dapat diterapkan pada materi pembelajaran lainnya sebagai penelitian lanjutan dalam penelitian ini.

\section{DAFTAR PUSTAKA}

Abimanyu, S. (2008). Strategi Pembelajaran. Jakarta: Direktorat Pendidikan Tinggi Departemen Pendidikan Nasional.

Anitah, S. (2009). Strategi Pembelajaran di SD. Jakarta: Universitas Terbuka.

Asmani, J. (2010). Tips Menjadi Guru Inspiratif, Kreatif, dan Inovatif. Yogyakarta: DIVA Press.

Djamarah, Bahri, S., \& Zain, A. (2010). Strategi Belajar Mengajar. Jakarta: Rineka Cipta.

Fadillah, A. (2016). Penerapan Metode Field Trip Untuk Meningkatkan Kemampuan Menulis Deskripsi Pada Siswa Kelas VIII SMP Negeri 1 Longat Panyabungan Barat. Jurnal Edukasi Kultura, 1-7.

Fathurrohman, P., \& Sutikno, M. (2015). Strategi Belajar Mengajar melalui Penanaman Konsep Umum \& Konsep Islami. Bandung: Refika Aditama.

Haling, A. (2007). Belajar dan Pembelajaran. Makassar: Badan Penerbit Universitas Negeri Makassar. 
Hamzah, A. (2014). Evaluasi Pembelajaran Matematika. Cetakan ke-1. Jakarta: PT Raja Grafindo Persada.

Prasetyo, A. (2015). Keefektifan Metode Field Trip Terhadap Hasil Belajar Sumber Daya Alam Siswa Kelas III SDN Bogangin 1 Kabupaten Banyumas. Skripsi. Universitas Negeri Semarang.

Ruhimat, A. Y. (2017). Teori dan Implementasi Pembelajaran Saintifik Kurikulum 2013. Bandung: Refika Aditama.

Slameto. (2010). Belajar dan Faktor-Faktor Yang Mempengaruhiya. Jakarta: Rineka Cipta.

Sutikno, M. S. (2009). Belajar dan Pembelajaran. Bandung: Prospect.

Wang, H. H., \& Carlson, S. P. (2011). Factors that Influence Student's Satisfaction in an Environmental Field Day Experience. International Electronic Journal of Environmental Education, 1(2), 129-139.

Yuliati, T., \& Martuti, N. K. (2014). Efektivitas Penerapan Metode Field Trip Untuk Meningkatkan Hasil Belajar Dan Kepedulian Siswa terhadap Lingkungan. Jurnal Pendidikan Matematika dan Sains, II(2), 178-187. 